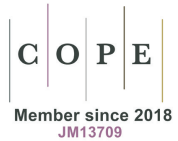

\title{
The Emperor in the Byzantine World. Papers from the Forty-Seventh Spring Symposium of Byzantine Studies, ed. SHAUN ToUGHER, Routledge, New York-London 2019 [ = Society for the Promotion of Byzantine Studies Publications, 21], 32 figures, index, pp. XXIII, 378.
}

$\mathrm{T}$ he publication being reviewed is a result of the Symposium of Byzantine Studies held in Cardiff between 25 and 27 April 2014; the symposium was devoted to the subject of the emperor in the Byzantine world. Fergus Millar's The Emperor in the Roman World $(31 B C-A D 337)^{1}$ was a direct inspiration for the Symposium's considerations because, as its editor claims, there is no equivalent in historiography with regard to the Byzantine emperors (p. 1$)^{2}$. The presented volume is divided into five Parts that define the axis of the undertaken issues: (1) Dynasty: Imperial families; (2) The emperor's men: Court and empire; (3) The emperor as ruler: Duties and ideals; (4) Imperial literature: Emperor as subject and author; and

\footnotetext{
${ }^{1}$ F. Millar, The Emperor in the Roman World (31 BC - AD 337), London 1977 [ $1^{\text {st }}$ ed.].

${ }^{2}$ However, it is worth mentioning, as S. Tougher also points out, that at the turn of the $20^{\text {th }}$ and $21^{\text {th }} \mathrm{c}$. the research interest concerning the role and position of women in Byzantine society has experienced significant growth, e.g. cf. M. DĄBROWSKA, Eacinniczki nad Bosforem. Małżeństwa bizatyńsko-łacińskie w cesarskiej rodzinie Paleologów (XIII-XV w.), Łódź 1996; L. GARLAND, Byzantine Empresses. Woman and Power in Byzantium, AD 527-1204, London-New York 1999; B. HiLl, Imperial Women in Byzantium 1025-1204. Power, Patronage and Ideology, London 1999; L. James, Empresses and Power in Early Byzantium, New York 2001; J. Herrin, Women in Purple. Rulers of Medieval Byzantium, London 2002. Furthermore, it is worth paying attention to the most recent studies on imperial power by R. BENOIT-MEgGENIS, L'empereur et le moine. Les relations du pouvoir impérial avec les monastères à Byzance, $I X^{e}-X I I I^{e}$ siècle, Lyon 2017 [= TMOM, 73].
}

(5) The material emperor: Image, spaces and empire. The volume is edited by Shaun Tougher, a Reader in Ancient History at Cardiff University, who specializes in the political and social history of the late Roman and Byzantine Empire ${ }^{3}$.

The substantial volume consists of seventeen chapters preceded by an Introduction (p. 1-10). Part 1 is opened by Mark Humphries' considerations on constructing the imperial legitimacy from Augustus to the Theodosians (p. 13-27). The author shows a wide range of measures that several emperors used to assure the imperial power of their dynasties, relying on bloodlines, marriages, adoptions or even constructed ancestry, as well as on other factors of dynastic legitimacy such as military success or religious rectitude. Mike Humphreys poses a question about the importance of a familial lens in the Heraclian ideology of the dynasty (p. 28-51). He argues that the Heraclians (from 610 to 681 ) sought legitimacy and a political base in their imperial family, but the situation changed after the deposition of co-emperors by Constantine IV and the limiting of succession to the eldest son. Mark Masterson examines Basil II's bachelorhood, claiming, through Symeon the New Theologian's Oratio Ethica 10, that there is an indication that the famous emperor had same-sex interests (p. 52-82). Dimitri Korobeinikov's chapter is a prosopographical study which shows the familial links between

\footnotetext{
${ }^{3}$ E.g. cf. S. Tougher, Julian the Apostate, Edinburgh 2007 [= DDAH]; IDEM, The Reign of Leo VI (886-912). Politics and People, Boston-Leiden 1997 [= MMe, 15].
} 
the Palaiologan dynasty and the Turks of the Rûm Sultanate (p. 83-111).

Part 2 is opened by Meaghan McEvoy's chapter about the political consequences of the celibacy of emperor Theodosius II's sisters, which led the dynasty to become extinct, and the familial policy of the aristocratic houses of Anthemii and Ardaburii, which, despite the upheavals, survived, briefly gained imperial power, and became related to other families ruling in the Empire (p. 115-134). Jonathan Shepard presents the political concept of Alexios I Komnenos in relation to the Latin West (p. 135-155). He argues that Alexios tried to reach a consensus with the Latins in order to promote the idea of a united Christendom under the leadership of Constantinople, which ultimately did not come to fruition. Jonathan Harris' chapter is devoted to the consistency of Constantine XI's imperial court, showing the importance of the political role played by the Emperor's moral authority in gaining and maintaining the loyalty of important noble figures such as Loukas Notaras (p. 156-167).

Part 3 begins with Bernard H. Stolte's chapter, which actually is a brief reconnaissance of the subject of the relation between the emperor, the law, and the lawyers (p. 171-178). Frank R. Trombley and Shaun Tougher study the prerogatives, duties and ideals of the Byzantine emperor in time of the war (p. 179-195). They show that the legacy of the Roman tradition was a crucial factor in establishing the military role of Byzantine emperors as a fundamental aspect of the reign, which was to be realized even by emperors who were not militarily active.

John Vanderspoel's chapter about the essence of imperial panegyrics opens Part 4 (p. 199-215). The author demonstrates the panegyrics not only as a literary tool for flattering the emperors, but also as a relay of imperial ideology, which could transmit a given political view to the broader public. Oscar Prieto Domínguez takes into account the process of shaping the image of emperor Theophilos in Byzantine hagiography (p. 216-234). It was presented that although Theophilos was in fact an iconoclast, and in some sources he was portrayed as a heretic or an opponent of the saints, his image drastically changed after the Triumph of Orthodoxy in 843, due to the actions of his wife Theodora, who tried to emphasize the deathbed conversion of her husband to justify the emperor's rehabilitation in the eyes of the Orthodox Church. Prerona Prasad, through the prefaces of the De ceremoniis, analyzes Constantine VII's view on dynastic succession and imperial ideology (p. 235-247). This chapter shows that Constantine VII believed that the act of capturing the Byzantine throne at the turn of 944/945 constituted a restoration of the legacy of Basil I, and a renewal of imperial majesty; previously, in the illegitimate and ignorant hands of the Lekapenoi that majesty was disgraced. Nikolaos G. Chrissis demonstrates the ideological climate at the court of Theodore Laskaris after the fall of Constantinople in 1204, focusing on the analysis of Niketas Choniates' orations and posing the question of Byzantine identity in the face of the Latins (p. 248-263). The author argues that Choniates tried to push the emperor, whose policy was too conciliatory, into a war against the Latin conquerors, also pointing to the Roman-Byzantine unity of Nicaea, Trebizond and Epirus, as victims of the very same enemy. Savvas Kyriakidis considers the image of the emperor in the History of John VI Kantakouzenos, which was coined in the conflict between Andronikos II and Andronikos III, supported by Kantakouzenos himself (p. 264-277). Such an image relies on the traditional idea of one being the absolute ruler and a juxtaposition of Andronikos III's prudence, philanthropy and other positive features with Andronikos II's harshness, old age and lack of military skills.

Part 5 is opened by Alicia Walker's chapter that describes the way in which imperial power was presented in Hagia Sophia's mosaics; she emphasizes the key role of the singular depiction of the emperor in the act of proskýnesis before Christ, placed over the so-called 'Imperial Door' (p. 281-321). She interprets the mosaic not as a representation of Leo VI's penitential state, but as a visual complement of the Constantine VII's Book of Ceremonies, related to imperial liturgical ceremonies, while other Hagia Sophia's mosaics constitute a conventional depiction of the rela- 
tionship between the imperial and the divine authorities, presenting the emperors as benefactors of the church, without earthly and cosmic 'taxis'. Lynn Jones argues that the concept of the 'imperial palace' should be broadened, not in terms of material culture, as a building or a complex of buildings, but as a palace on the move, i.e. 'the campaign palace' basing on the emperor's presence and fulfilling ceremonial or administrative functions outside Constantinople (p. 322-340). Mark Redknap's final chapter describes the Byzantine archaeological findings, especially the Byzantine coins, in the collection of Amgueddfa Cymru (National Museum Wales), showing the connection between Wales and the Eastern Empire (p. 341-371).

The presented volume tries to fill a gap in the research field and brings new approaches to the study of the Byzantine emperor. Scientifically, the volume is of high quality. However, it should be noted that the chapters display large structural diversity; most of them provide exhaustive presentation of the posed issues, while others are just a small sketch of the topic (e.g. Bernard H. Stolte's chapter). Furthermore, the reader may get the impression that the last chapter is only loosely related to the main subject. It would certainly be beneficial for the volume if the authors cited the achievements of scholars writing in Slavic languages. Even though it is worth emphasizing that the volume cannot be considered a comprehensive monograph on the emperor in the Byzantine world, it aims to present a large scope of thematic and chronological diversity. It has not exhausted the topic, but constitutes a basis for further discussion and work. It should be noted that these criticisms do not deprive the volume of its high cognitive value.

\section{BIBLIOGRAPHY}

Benoit-Meggenis R., L'empereur et le moine. Les relations du pouvoir impérial avec les monastères à Byzance, $I X^{e}-X I I I^{e}$ siècle, Lyon 2017 [ = Travaux de la Maison de l'Orient et de la Méditerranée, 73], https://doi. org/10.4000/books.momeditions. 2136
DĄBrowska M., Łacinniczki nad Bosforem. Matżeństwa bizatyńsko-łacińskie w cesarskiej rodzinie Paleologów (XIII-XVw.), Łódź 1996.

Garland L., Byzantine Empresses. Woman and Power in Byzantium, AD 527-1204, London-New York 1999.

Herrin J., Women in Purple. Rulers of Medieval Byzantium, London 2002.

Hill B., Imperial Women in Byzantium 1025-1204. Power, Patronage and Ideology, London 1999.

James L., Empresses and Power in Early Byzantium, New York 2001.

Millar F., The Emperor in the Roman World (31 BC - AD 337), London 1977.

Tougher S., Julian the Apostate, Edinburgh 2007 [= Debates and Documents in Ancient History].

Tougher S., The Reign of Leo VI (886-912). Politics and People, Boston-Leiden 1997 [= The Medieval Mediterranean, 15].

Tomasz Pełech (Wrocław/Clermont-Ferrand)* iD https://orcid.org/0000-0002-3722-568X

${ }^{*}$ University of Wrocław/Université Clermont-Auvergne 